\title{
Morphological and immunohistochemical compare of three rat prostate lobes (lateral, dorsal and ventral) in experimental hyperprolactinemia.
}

\author{
Sylwia Słuczanowska-Gląbowska ${ }^{1}$, Maria Laszczyńska ${ }^{2}$, Marcin Wylot ${ }^{3}$, \\ Wojciech Gląbowski ${ }^{3}$, Małgorzata Piasecka ${ }^{2}$, Dariusz Gącarzewicz ${ }^{4}$
}

\author{
${ }^{1}$ Department of Physiology Pomeranian Medical University Szczecin, Poland \\ ${ }^{2}$ Laboratory of Histology and Developmental Biology Pomeranian Medical University Szczecin, Poland \\ ${ }^{3}$ Department of Histology and Embryology Pomeranian Medical University Szczecin, Poland \\ ${ }^{4}$ West Pomeranian University of Technology Department of Animal Reproduction Biotechnology and \\ Environmental Hygiene, Faculty of Biotechnology and Animal Breeding Szczecin, Poland
}

\begin{abstract}
The prolactin plays an important role in the regulation of growth and differentiation of prostate gland besides androgens. The goal of this study was to reveal the influence of elevated prolactin concentration on epithelial cells of prostate. We compared the morphology of epithelial cells of prostate dorsal, lateral and ventral lobes and expression of androgen receptors in these cells in rats with hyperprolactinemia and in control rats. We used sexually mature male Wistar rats. The experimental rats received metoclopramide; the control group received saline in the same way. The prostate dorsal, lateral and ventral lobes were collected routinely for light and electron microscopy. The intensity of immunohistochemical reaction of androgen receptor in epithelial cells of dorsal, lateral and ventral lobes was evaluated by measure of optical density with computer image analysis. The light and electron (transmission and scanning) microscopes were used for morphological observations. Results: In experimental rats twofold increase in prolactin and twofold decrease in testosterone found. In experimental group the expression of androgen receptor was lower in columnar epithelial cells of dorsal and ventral lobes but higher in lateral one. We observed morphological abnormalities in columnar epithelial cells of lateral and dorsal lobes. The columnar epithelial cells of ventral lobes didn't show any morphological changes in hyperprolactinemia.
\end{abstract}

Key words: hyperprolactinemia, androgen receptor, prostate lobes, testosterone, prolactin

\section{Introduction}

General pattern of prostate gland is common to all the rodents and human, however there are important details differing species. Rat prostate reveals evident lobular structure, whereas adult human one is encapsulated with connective tissue, which enables recognition of distinct lobes. The rat prostate is divided into distinct ventral, dorsal and lateral lobe pairs (VP, DP, LP) according to relative position to urine bladder. [1]. Human prostate reveals lobes only in early development. Afterward connective tissue joins lobes in one solid gland. In the 1980-ies McNeal introduced clini-

Correspondence: M. Laszczyńska, Laboratory of Histology and Developmental Biology, Pomeranian Medical University, Żołnierska 48, 71-210 Szczecin, Poland; e-mail:

laszcz@sci.pam.szczecin.pl cal division of prostate into four zones: the anterior, central, peripheral and transitional according to urethra position $[2,3]$. Each lobe of the rat prostate is formed with secretory portions and branching excretory ducts system, embedded in delicate stroma. In ventral and lateral lobes there are a few main ducts with innumerous but wide branches similar to oak tree branching, whereas in dorsal lobe there are numerous main duct with narrow, short but numerous branches similar to palm tree branching [4]. There also is visible unequal proportion epithelium/connective tissue between rodents $5 / 1$ and human 1/1. [1]

The function of prostate gland is mainly regulated by androgens. These steroid hormones are responsible for growth, proliferation and inhibit death (survival) of epithelial cells [5]. Their biological effects are mediated by androgen receptors (AR). This receptor is located both in man and woman in different age and also in 
different organs, but not only in male and female reproductive system $[5,8]$. There are two forms of these receptors: nuclear and cytosolic [9]. In rats AR were detected in all three lobes of prostate, mainly in epithelial but also in stromal cells. The androgen receptors were not detected in basal cells of rats, but in human - these receptors were detected in basal and columnar cells $[5,10,11]$. In rats the regulation of AR expression is different in three separate lobes. Nuclear AR expression, in ventral and dorsal lobes, is primary regulated by androgens, but in the lateral lobe it is androgen independent. Cytosolic AR has not been detected in lateral lobe. In dorsal and ventral lobes cytosolic AR expression is regulated by androgen [9]. The other hormone, which regulates the expression of AR is prolactin (PRL), but this only a case of lateral lobe epithelial cells [12].

Prolactin affects the morphology and function of prostate [13-19]. The hormone is derived not only from pituitary gland but also is synthesized locally in prostate $[20,22]$. Nevalainen et al. [20] observed locally synthesis of PRL in lateral and dorsal lobe of rat prostate. The PRL is produced in epithelial cells [21] and in smooth muscles of human prostate too [22].

Prolactin is a physiological regulator of prostate activities and plays an important role in prostate growth, development, proliferation and function. The lateral lobe of rat prostate is an essential target for PRL. The lateral, dorsal and coagulating lobes are homologous with the human prostate $[13,15]$. The biological effect of PRL is mediated by membrane bound receptors [23]. In rats the prolactin receptors are located in epithelial cells of all three lobes, in basal, lateral and apical parts of the cells $[10,24,26]$. The major function of the prostate is the production and secretion of high levels of citrate. This unique function in lateral lobe is dependent of PRL, but in ventral lobe is dependent of testosterone [15]. The PRL and T are response of prostate uptake of zinc. The lateral lobe accumulates the highest amount of zinc as compared to other tissues of the organism $[15,17]$. The PRL stimulates secretion of prostate proteins and conversion $\mathrm{T}$ to DHT [14,15,27].

The hyperprolactinemia influences morphology and function of prostate $[28,30]$. Prins $[10,12]$ showed that hyperprolactinemia affects the morphology and the function of rat prostate lateral lobe only. Van Coppenolle et al. [25] observed that chronic hyperprolactinemia induced enlargement and inflammation of the lateral lobe without any histological changes on ventral and dorsal lobes. Ahonen and et al. [19] showed that PRL acts as a survival factor for epithelial cells of dorsal and lateral lobe, but not for ventral prostate. The prolactin does not influence on the ventral lobe $[15,25,26,29]$. However, the ventral lobe is more sensitive for androgens and estrogens [31,32].
Table 1. Prolactin (PRL) and testosterone (T) serum concentrations in control rats and in rats receiving $\mathrm{MCP}$ (mean $\pm \mathrm{SD}$ ).

\begin{tabular}{|l|c|c|}
\hline \multicolumn{1}{|c|}{ Group } & $\begin{array}{c}\text { PRL }(\mathrm{ng} / \mathrm{mL}) \\
\mathrm{M} \pm \mathrm{SD}\end{array}$ & $\begin{array}{c}\mathrm{T}(\mathrm{ng} / \mathrm{mL}) \\
\mathrm{M} \pm \mathrm{SD}\end{array}$ \\
\hline Control & $13,7 \pm 3,4$ & $3,42 \pm 1,9$ \\
\hline Experimental & $28,6 \pm 5,2 * * *$ & $1,35 \pm 0,8 *$ \\
\hline
\end{tabular}

We have reported previously that hyperprolactinemia following administration of different drug in male rats influenced the expression of AR and caused morphological changes in the epithelial cells of lateral prostate and dorsal lobes independently from decrease of testosterone serum level [28-30,33]. The goal of this study was to compare the expression of AR in epithelial cells of lateral, dorsal and ventral lobes and morphology of these cells in experimental hyperprolactinemia.

\section{Materials and methods}

Animals. The experiments were performed on 20 sexually mature male rats of Wistar strain. The animals were randomly divided into control and experimental group. To induce hyperprolactinemia the experimental rats were given metoclopramide (MCP, Polfa Starogard Poland) intraperitonealy in a dose of 2.2 $\mathrm{mg} / \mathrm{kg}$ b.w. for 14 days (duration of rat seminiferous epithelium cycle). The rats of control group were given saline in the same way. The three lobes of rat prostate (lateral, dorsal and ventral) were routinely collected for light and electron microscopy. The blood was collected from heart for evaluation of serum hormones concentrations.

Hormone analysis. Prolactin (PRL) serum levels were measured with rat prolactin ELISA enzyme immunoassay kit (Spi-Bio, France). Testosterone (T) serum levels were measured with radioimmunoassay kit (Farmos Diagnostika, Finland).

Morphology. Prostate lobes were obtained during section. For morphological studies prostate lobes were fixed in Bouin's solution and embedded in paraffin. Morphological analysis was carried out after hematoxylin-eosin $(\mathrm{H}+\mathrm{E})$ staining.

Transmission electron microscopy (TEM). Prostate dorsal lobe was cut into $1 \mathrm{~mm}^{3}$ pieces, fixed in $0.25 \mathrm{~mol} / 1$ glutaraldehyde in $0.1 \mathrm{~mol} / \mathrm{l}$ cacodylate buffer $(\mathrm{pH} 7.4)$ for $2 \mathrm{~h}$ at $4{ }^{\circ} \mathrm{C}$, postfixed in $1 \%$ $\mathrm{OsO}_{4}$, dehydrated in ethyl alcohol (30-96\%) and $100 \%$ acetone, and subsequently embedded in Spurrr's resin (Polysciences, Inc.). The blocks were cut with Reichter $\mathrm{OmU}_{2}$ ultramicrotome. The ultra-thin sections were contrasted with uranyl acetate as well as lead citrate, and examined under JEM-1200 EX transmission electron microscope.

Scanning electron microscopy (SEM). The specimens for SEM were washed with phosphate buffered solution (PBS), fixed in $0.25 \mathrm{~mol} / 1$ glutaraldehyde in $0.1 \mathrm{~mol} / 1$ cacodyle buffer $(\mathrm{pH} 7.4$ ) for $3 \mathrm{~h}$ at $4^{\circ} \mathrm{C}$. The material was washed again with the bufferand postfixed in $1 \% \mathrm{OsO}_{4}$, dehydrated in ethyl alcohol $(30-96 \%)$ and $100 \%$ acetone. The slides were dried with liquid $\mathrm{CO}_{2}$ and covered with gold and palladium. The material was examined under a JEOLJSM-6100 scanning electron microscope. 
Table 2. Parameters of immunohistochemical reaction to AR in the nuclei of epithelial columnar cells in lateral, dorsal and ventral lobes of prostate in control rats and in rats receiving $\mathrm{MCP}($ mean $\pm \mathrm{SD})$.

\begin{tabular}{|l|c|c|c|c|c|c|}
\hline \multirow{2}{*}{} & \multicolumn{4}{|c|}{ Nuclei of epithelial columnar cells of rat prostate } \\
\cline { 2 - 7 } & \multicolumn{2}{|c|}{ Lateral lobe } & \multicolumn{2}{|c|}{ Dorsal lobe } & \multicolumn{3}{c|}{ Ventral lobe } \\
\cline { 2 - 7 } & $\begin{array}{c}\text { Control } \\
(\mathrm{n}=575)\end{array}$ & $\begin{array}{c}\text { Experimental } \\
(\mathrm{n}=611)\end{array}$ & $\begin{array}{c}\text { Control } \\
(\mathrm{n}=575)\end{array}$ & $\begin{array}{c}\text { Experimental } \\
(\mathrm{n}=611)\end{array}$ & $\begin{array}{c}\text { Control } \\
(\mathrm{n}=598)\end{array}$ & $\begin{array}{c}\text { Experimental } \\
(\mathrm{n}=603)\end{array}$ \\
\hline $\begin{array}{l}\text { Integrated optical density } \\
\text { (IOD) }\end{array}$ & $\begin{array}{c}490 \\
(354-685)\end{array}$ & $\begin{array}{c}551^{* * *} \\
(438-720)\end{array}$ & $\begin{array}{c}810 \\
(554-1205)\end{array}$ & $\begin{array}{c}763^{*} \\
(557-1027)\end{array}$ & $\begin{array}{c}736 \\
(559-974,5)\end{array}$ & $\begin{array}{c}65 * \\
(519-882)\end{array}$ \\
\hline $\begin{array}{l}\text { Mean optical density } \\
\text { (MOD) }\end{array}$ & $\begin{array}{c}0,56 \\
(0,51-0,87)\end{array}$ & $\begin{array}{c}0,76^{* * *} \\
(0,68-0,84)\end{array}$ & $\begin{array}{c}0,84 \\
(0,76-0,90)\end{array}$ & $\begin{array}{c}0,81 * \\
(0,74-0,89)\end{array}$ & $\begin{array}{c}0,97 \\
(0,88-1,03)\end{array}$ & $\begin{array}{c}0,94 * \\
(0,88-1)\end{array}$ \\
\hline
\end{tabular}

$* * *-p<0,001 ; *-p<0,05$

Immunohistochemistry. The expression of AR was determinated immunohistochemically in paraffin-embedded specimens fixed in $4 \%$ buffered formalin. The reaction was performed on deparaffinized and rehydrated sections $(3 \mu \mathrm{m})$. The radiation of microwave oven $(250 \mathrm{~W})$ was applied for $30 \mathrm{~min}$ in citrate buffer. The endogenous peroxidase was inhibited with $3 \% \mathrm{H}_{2} \mathrm{O}_{2}$ in methanol for $10 \mathrm{~min}$. The nonspecific binding sites were blocked with 3\% normal goat serum (Sigma, USA) for $30 \mathrm{~min}$. The sections were incubated overnight at $4 \mathrm{oC}$ with primary antibody: the polyclonal antibody against androgen receptor (NCL-ARp, 1:10, Novocastra Lab, Ltd Newcastle, UK) and subsequently, with secondary antibody, biotinylated goat anti-rabbit $\operatorname{IgG}(1: 400$, Vector Lab., Burlingame, CA, USA) for $60 \mathrm{~min}$. In the next step, avidin-biotinhorseradish peroxidase complex (ABC/HRP; 1:100, Dako/AS, Denmark) was applied for $30 \mathrm{~min}$. Diaminobenzidine (DAB) was used to visualize the immunohistochemical reaction. The sections were counterstained with Mayer's haematoxylin. In the control reaction, the primary antibody was replaced by normal goat serum. After each step, sections were rinsed with Tris-buffered saline (TBS). Finally, sections were examined with light microscope.

Computer image analysis. To enable the quantitative evaluation of the intensity of immunohistochemical reaction of AR, the optical density was measured and analyzed with the computer image analyzer (Quantimet $600 \mathrm{~S}$, Leica, UK). The optical density of the immunohistochemical reaction product was related (matched) to the density of AR. The system was calibrated, light transmittance replacing grey levels (range $0-255$ ) with the value of optical density in the range of $0-2$. The microscopic image was analyzed at $\times 400$ magnification and next transmitted as a monochromatic (grey) image to the computer system. For statistical analysis integrated optical density (IOD) and mean optical density (MOD) values were counted to estimate the intensity of immunohistochemical reaction (for AR) in nuclei of 600 columnar epithelial cells in each group.

Statistical analysis. Serum prolactin and testosterone concentrations were analyzed by the Cochran-Cox test. Parameters of integrated and mean optical density (IOD and MOD) were analyzed by the Mann-Whitney U-test. Statistical significance was accepted at $\mathrm{p}<0.05$.

\section{Results}

In rats of the experimental group as compared to the control group, the mean PRL serum concentration was more than 2 times higher $(28.6 \pm 5.2$ vs. $13.7 \pm 3.4 \mathrm{ng} / \mathrm{ml}$ ) whereas the mean $\mathrm{T}$ concentration was about 2 times lower $(1.35 \pm 0.8$ vs. $3.42 \pm 1.9$ $\mathrm{ng} / \mathrm{ml})$ (Table 1).

As compared to the control group light microscope (LM), TEM and SEM showed the following changes in morphology of epithelial cells of prostate lobes in rats with hyperprolactinemia.

In light microscopy (LM) we observed focal proliferation of epithelium in lateral lobe in rats with hyperprolactinemia. The columnar and cubical cells of epithelium were tall and they had irregular disposition in sites of hyperplasia (Fig. $1 \mathrm{~A}, \mathrm{~B}$ ). In the epithelial cells of lateral lobe in rats with hyperprolactinemia we observed in TEM and SEM widened cysternae of the rough endoplasmic reticulum (RER) and Golgii apparatus, reduced number of dense granules in these cells, small numbers of microvilli and poor secretory material at the surface [28].

In LM we also observed focal proliferation of epithelial cells in dorsal lobe in rats with hyperprolactinemia. The columnar cells of epithelium were tall (Fig. $1 \mathrm{C}, \mathrm{D}$ ). In the majority of columnar epithelial cells of prostate dorsal lobe we observed in TEM and SEM highly dilated RER cisternae, small number of microvilli at the surface but the apical blebs were observed in glandular lumen in both control as well as experimental animals [30].

In LM the epithelial cells of ventral lobe in rats with hyperprolactinemia was shorter than cells of ventral lobe of control rats. We observed only focal atrophy in the epithelium (Fig. 1 E, F). The columnar epithelial cells of ventral lobe did not show any changes as well as columnar epithelial cells of lateral and dorsal lobes in TEM and SEM.

Immunohistochemical study showed different expression of AR in the nuclei of columnar epithelial and stromal cells of lateral, dorsal and ventral prostate lobes in the experimental as well as in the control group (Fig. 2). In rats with hyperprolactinemia, the nuclei of epithelial cells of dorsal and ventral lobes revealed lower optical density of immunocytochemical reaction (week expression) as compared to control 
rats (strong expression). A significant decrease $(\mathrm{p}<0.05)$ in both IOD and MOD was noted in the experimental animals. In the lateral lobe we found higher optical density of immunocytochemical reaction in experimental rats (strong expression) as compared to control rats (week expression). A significant increase $(p<0.001)$ in both IOD and MOD was noted in the experimental animals (Table 2, Fig. 2).

\section{Discussion}

In the study we compared the structure of the columnar cells as well as expression of androgen receptor in three lobes of rat prostate under conditions of hyperprolactinemia induced with metoclopramide.

We showed that intraperitoneal administration of MCP in dose $2.2 \mathrm{mg} / \mathrm{kg}$ body weight provoked hyperprolactinemia in rats. By immunoassay we found more than twofold increase in prolactin serum concentration in rats receiving $\mathrm{MCP}$ as compared to the control group. It is consistent with our previous results obtained with radioimmunoassay $[34,36]$. It is worth to notice the results obtained with immunoassay as well as those determined with radioimmunoassay in our previous study were comparable $(28.6 \pm 5.2$ and

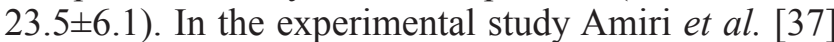
used even doubled dose of MCP than we were for 21 days and found 2,5 fold increase of PRL concentration comparing to control rats. The capability of MCP to induce hyperprolactinemia was reported by others too $[38,40]$.

We measured also concentration of testosterone in serum and we noted a significant, more than twofold decrease of mean $\mathrm{T}$ serum concentration in animals treated with $\mathrm{MCP}$ when compared to control group. The similar results were reported in previous studies $[34,36,39]$. In another experimental model using different drug to induce hiperprolactinemia, reduced $\mathrm{T}$ serum concentration was also reported [41].

In our study we determined the AR immunoexpression in epithelial columnar cells and stromal cells of all three rat prostate lobes. However we did not observed AR in epithelial basal cells. The other authors made similar observations $[5,9,10]$.

By computer image analysis using immunohistochemical reaction product IOD and MOD measurements were evaluated and subsequently AR expression in columnar epithelial cells of rat prostate lateral, dorsal and ventral lobes were compared between experimental and control groups. In the epithelial columnar cells of lateral lobe the higher immunoexpression of AR was found in rats with hyperprolactinemia comparing to control rats. On the other hand in dorsal and ventral lobes the AR expression was lower in experimental rats then in control ones. Higher AR expression in lateral lobe of hyperprolactinemic rats may be explained by several mechanisms. Banerjee et al. [5] reported that AR expression in rat lateral lobe did not change following castration because it is not dependent on serum $\mathrm{T}$ concentration. Another research suggested that there is androgen independent regulation of AR expression in lateral lobe, dissimilar to others prostate lobes [6]. The experimental rat study of Prins [12] revealed that increased PRL causes up regulation of AR expression only in lateral lobe as the most prolactin dependent one. Moreover, the decrease of $\mathrm{T}$ serum level causes the lateral lobe is even more sensitive to prolactin [42]. The others also shown that the lateral lobe is the most sensitive to prolactin [15].

We also assessed the effect of hyperprolactinemia on morphology of columnar epithelial cells of rat prostate lateral, dorsal and ventral lobes using light as well as transmission and scanning electron microscopy.

In lateral lobe the epithelium was tall and ultrastructural changes of SER, RER, Golgi apparatus and the cell surface were observed only in some columnar cells in experimental group. Secretory granules containing electron dense material were found in both experimental and control rats. Since RER, Golgi apparatus and the cell surface are related to androgen dependent function of lateral lobe, the structural abnormalities of these organelles might be caused by reduced $\mathrm{T}$ serum level secondary to $\mathrm{MCP}$ administration. It is well known the androgens are responsible for development, maturation and function of the prostate $[5,20,43,44]$. The recent studies have shown that proteins synthesized in epithelial cells of prostate lateral lobe like probazin, SVSII or -microseminoprotein are androgen dependent [45]. It is possible the reduced testosterone serum level, despite higher AR expression, was not strong enough to maintain proper protein synthesis within the cells. On the other hand, the occurrence of secretory granules with electron dense material, reported previously as granules containing zinc [46], is likely associated with zinc accumulation rate. In the lateral lobe it is the highest and is controlled not only with testosterone but also with PRL $[15,47]$.

The ultrastructural changes of rough endoplasmic reticulum were observed in prostate dorsal lobe of rats suffering hyperprolactinemia too. The epithelial columnar cells of this lobe were also tall. In some cells RER was strongly vacuolated and in the others the cisterns were bloated. Reduced serum testosterone level as well as lower AR expression in dorsal lobe epithelial columnar cells in rats suffering hyperprolactinemia might influence the structure of organelles associated with protein synthesis. It is known the synthesis of majority of proteins in dorsal lobe depends on androgens [48]. 

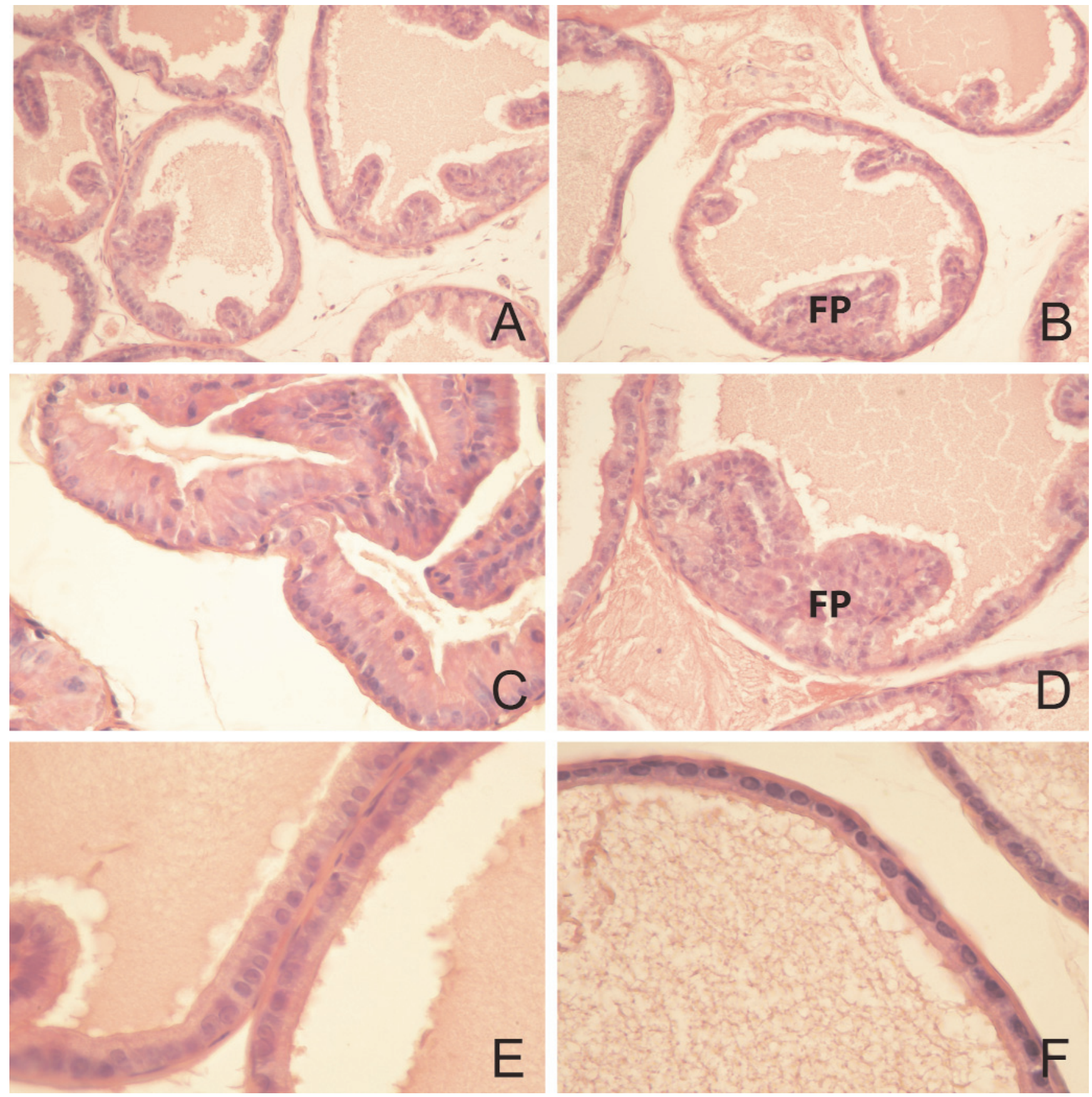

Fig. 1. The prostate lateral, dorsal and ventral lobes of control rat and rat receiving MCP. Epithelial cells of prostate lateral lobe of control rat $(\mathbf{A})$ and rat receiving $\mathrm{MCP}(\mathbf{B})($ magnification $\times 100)$. Epithelial cells of prostate dorsal lobe of control rat $(\mathbf{C})($ magnification $\times 400)$ and rat receiving MCP $(\mathbf{D})$ (magnification $\times 200$ ). Focal proliferation $(\mathrm{FP})$ of epithelium of prostate lateral and dorsal lobe in rat receiving $\mathrm{MCP}(\mathbf{B}, \mathbf{D})$. Epithelial cells of prostate ventral lobe of control rat $(\mathbf{E})$ and rat receiving $\mathrm{MCP}(\mathbf{F})$. The shorter epithelium in ventral lobe of rat receiving $\mathrm{MCP}(\mathbf{F})$ than in epithelium of control rat $(\mathbf{E})$ (magnification $\times 400)$. H+E staining.

In the ventral lobe however the shorter epithelial columnar cells and focal atrophy of the epithelium were observed in experimental group. It could be related to higher sensitivity of ventral lobe to decreased testosterone level. The ultrastructure of the cellular organelles was not markedly impaired. It is with agreement with the other authors that reported the elevated
PRL did not influenced the columnar cells of ventral lobe, which is highly sensitive to androgens $[15,25,29]$.

It is well known so far that hyperprolactinemia causes morphological abnormalities in prostate cells [25,49]. Van Coppenolle et al. [25] determined the hyperprolactinemia induced with sulpirid caused 

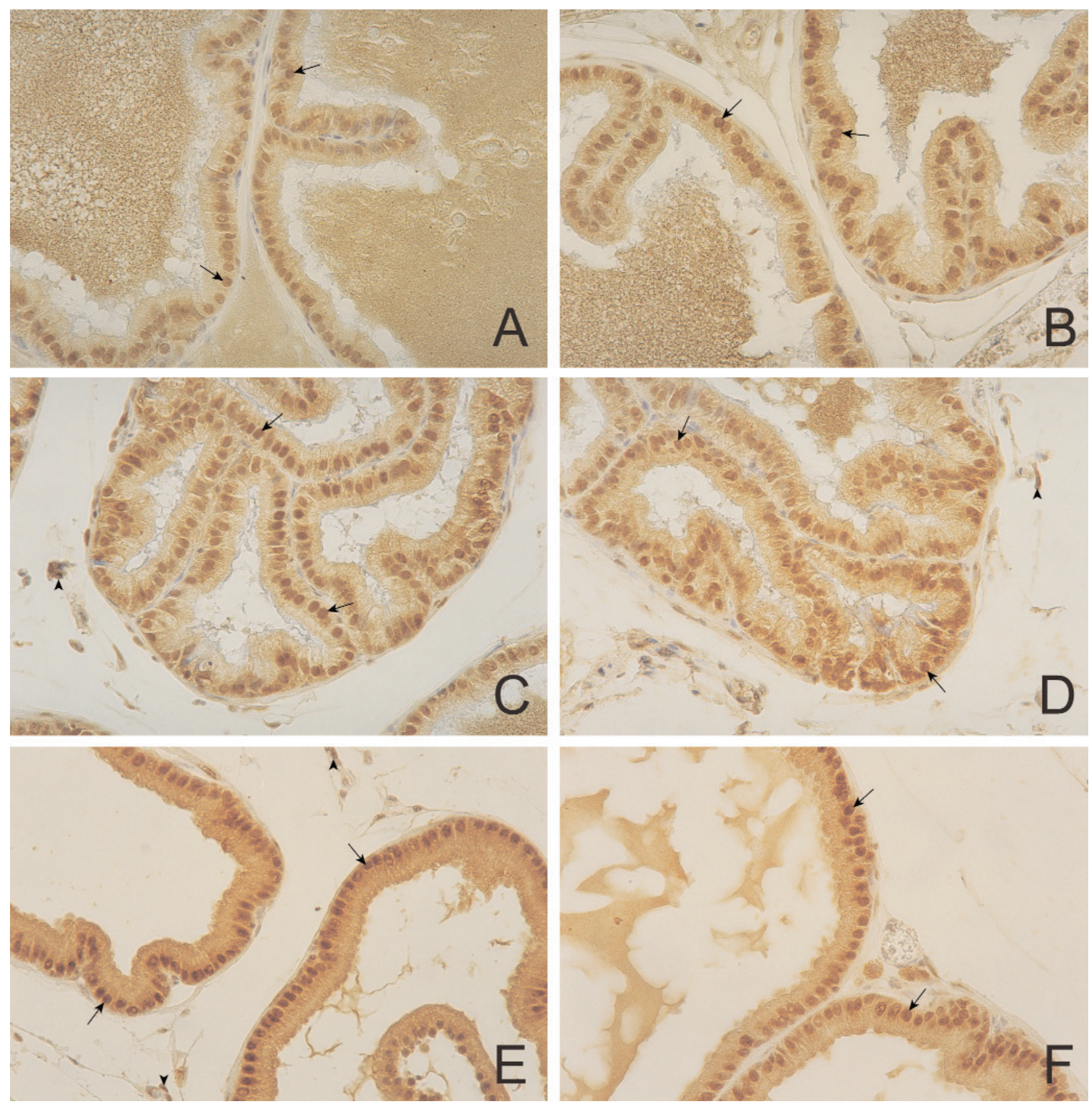

Fig. 2. Immunohistochemical nuclear localization of androgen receptor (AR) in the epithelial (arrow) and stromal (arrowhead) cells of three lobes of rat prostate (lateral, dorsal and ventral). Nuclear expression of AR in epithelial cells of prostate lateral lobe of control rat week expression (A) and strong in rat receiving MCP (B); strong nuclear expression of AR in epithelial cells of prostate dorsal $(\mathbf{C})$ and ventral (E) lobes of control rat and week nuclear expression of AR in epithelial cells of prostate dorsal (D) and ventral (F) lobes in rat receiving MCP (magnification $\times 200)$.

epithelial cells hyperplasia only in lateral lobe but not in dorsal and ventral ones. On the other hand Ahonen et al. [49] found the hyperprolactinemia caused hyperplasia in both lateral and dorsal lobes. Another group reported that in mice stimulated with PRL the hyperplasia of stromal and epithelial prostate cells occur independently on androgen level [50].
Based on our observations we can conclude that (I) experimental hyperprolactinemia induced with metoclopramide in rats caused structural changes in prostate cells expressing AR and (II) testosterone and prolactin serum levels regulate the AR expression in the prostate. Ultrastructural abnormalities in prostate epithelial columnar cells were found mostly in 
organelles engaged in protein and glicoprotein synthesis or discharge and might be the reason of the infertility of the animals.

\section{References}

[1] Bartsch G, Rohr HP. Comparative light and electron microscopic study of the human, dog and rat prostate. Urol Int. 1980;35:91-104.

[2] McNeal JE. The zonal anatomy of prostate. Prostate. 1981;2: 35-49.

[3] Wendell Smith C. Terminology of prostate and related structures. Clin Anat. 2000;13:207-213.

[4] Hayashi N, Sagimura Y, Kawamura J, Donjacour AA, Cunha GR. Morphological and functional heterogeneity in the rat prostatic gland. Biol Reprod. 1991;45:308-321.

[5] Banerjee PP, Banerjee S, Brown TR. Increased androgen receptor expression correlates with development of age dependent, lobe-specific spontaneous hyperplasia of brown norway rat prostate. Endocrinology. 2001;142:4066-4075.

[6] Agrawal AK, Jeleń M, Grzebieniak Z, Żukrowski P, Rudnicki J, Nienarowicz E. Androgen receptors as prognostic and predictive factor in breast cancer. Folia Histochem Cytobiol. 2008;46:269-276.

[7] Walczak-Jędrzejowska R, Słowikowska-Hiczer J, Marchlewska K, Oszukowska E, Kula K. Administration of testosterone inhibits initiation of seminal tubule growth and decreases Sertoli cell number in the earliest period of rat's postnatal development. Folia Histochem Cytobiol. 2009;47: S149-S154.

[ 8] Brodowska A, Laszczyńska M, Starczewski A, Brodowski J, Masiuk M, Domagała W. Immunohistochemical analysis of steroid receptors in ovaries of postmenopausal women effects of aging and hormone status. Histol Histopathol. 2010;25:1009-1016.

[9] Prins GS. Differential regulation of androgen receptors in the separate rat proastate lobes: androgen independent expression in the lateral lobe. $J$ Steroid Biochem. 1989;33:319-326.

[10] Prins GS, Birch L, Greene G. Androgen receptor localization in different cell types of adult rat prostate. Endocrinology. 1991;129:3187-3199.

[11] Pelletier G, Labrie C, Labrie F. Localization of oestrogen receptor oestrogen receptor and androgen receptors in the rat reproductive organs. $J$ Endocrinol. 2000;165:359-370.

[12] Prins GS. Prolactin influence on cytosol and nuclear androgen receptors in the ventral, dorsal, and lateral lobes of the rat prostate. Endocrinology. 1987;120:1457-1464.

[13] Laszczyńska M. Role of prolactin in male reproductive system. Post Biol Kom. 2002;29:45-59.

[14] Reiter E, Hennuy B, Bruyninx M, Cornet A, Klug A, McNamara M, Closset J, Hennen G. Effect of pituitary hormones on the prostate. Prostate. 1999;38:159-165.

[15] Costello LC, Franklin RB. Effect of prolactin on the prostate. Prostate. 1994;24:162-166.

[16] $\mathrm{Xu} \mathrm{X,} \mathrm{Wu} \mathrm{W,} \mathrm{Williams} \mathrm{V,} \mathrm{Khong} \mathrm{A,} \mathrm{Chen} \mathrm{YH,} \mathrm{Deng} \mathrm{C,}$ Walker A M. Opposite effects of unmodified prolactin and molecular mimic of phosphorylated prolactin on morphology and the expression of prostate specific genes in the normal rat prostate. Prostate. 2003;54:25-33.

[17] Liu Y, Franklin RB, Costello LC. Prolactin and testosterone regulation of mitochondrial zinc in prostate epithelial cells. Prostate. 1997;30:26-32.

[18] Bartke A. Prolactin in the male: 25 years later. $J$ Androl. 2004;25:661-666.

[19] Ahonen TJ, Harkonen PL, Laine J, Rui H, Martkainen PM, Nevalainen MT. Prolactin is a survival factor for androgen- deprived rat dorsal and lateral prostate epithelium in organ culture. Endocrinology. 1999;140:5412-5421.

[20] Nevalainen MT, Valve EM, Ahonen T, Yagi A, Paranko J, Harkonen PL. Androgen-dependent expression of prolactin in rat prostate epithelium in vivo and in organ culture. FASEB J. 1997;11:1279-1307.

[21] Nevalainen MT, Valve EM, Ingleton PM, Nurmi M, Martikainen PM, Härkönen PL. Prolactin and prolactin receptors are expressed and functioning in human prostate. J Clin Invest. 1997;99:618-627.

[22] Untergasser G, Rumpold H, Plas E, Witkowski M, Berger P. Seminal plasma factors induce in vitro PRL secretion in smooth muscle cells of the human prostate. J Clin Endocrinol Metab. 2001;86:5577-5584.

[23] Nevalainen MT, Valve EM, Ingleton PM, Härkönen PL. Expresion and hormone regulation of prolactin receptors in rat dorsal and lateral prostate. Endocrinology. 1996;137: 3078-3088.

[24] Wylot M, Laszczyńska M, Słuczanowska-Głąbowska S. Prolactin receptors in human and various animal species. Post Biol Kom. 2004;4:749-761.

[25] Van Coppenolle F, Slomianny C, Carpentier F, Le Bourhis X, Ahidouch A, Croix D, Legrand G, Dewailly E, Fournier S, Cousse H, Authie D, Raynaud JP, Beauvillain JC, Dupouy JP, Prevarskaya N. Effect of hyperprolactinemia on rat prostate growth: evidence of androgeno-dependence. Am J Physio Endocrinol Metab. 2001;280:E120-E129.

[26] Van Coppenolle F, le Bourhis X, Capentier F, et al. Pharmacological effects of the lipidosterolic extract of Serenoa repens (Permixon) on rat prostate hyperplasia induced by hyperprolactinemia; comparison with Finasteride. Prostate. 2000;43:49-58.

[27] Bole-Feysot C, Goffin V, Edery M, Binart N, Kelly PA. Prolactin (PRL) and its receptor: actions, signal transduction pathways and phenotypes observed in PRL receptor knockout mice. Endocrinol. Rev. 1998;19:225-268.

[28] Słuczanowska-Głąbowska S, Laszczyńska M, Wylot M, Piasecka M, Kram A. The expression of androgen receptors in the epithelial cells of the rat prostate lateral lobe in experimental hyperprolactinemia: a morphological and immunohistochemical study. Folia Morphol. 2003;62:501503.

[29] Słuczanowska-Głabowska S. The effect of hyperprolactinemia on morphology and function of androgen receptor expressing cells on rat testis, epididymis and prostate. Ann Acad Med Stetin. 2004;50:123-134.

[30] Słuczanowska-Głąbowska S, Laszczyńska M, Głąbowski W, Wylot M. Morphology of the epithelial cells and expression of androgen receptor in rat prostate dorsal lobe in experimental hyperprolactinemia. Folia Histochem Cytobiol. 2006;44: 25-30.

[31] Aumuller G, Braun BE, Seitz J et al. Effects of sexual activity on the structure and function of the ventral prostate of the rat. Anat Rec. 1985;212:345-352.

[32] Aumuller G. Morphologic and regulatory aspects of prostatic function. Anat Embryol. 1989;179:519-531.

[33] Wylot M, Laszczyńska M, Słuczanowska-Głąowska S. Aging process of epithelial cells of the rat prostate lateral lobe in experimental hyperprolactinemia induced by haloperidol. Ann Acad Med Bialostocensis. 2004;49:111-113.

[34] Laszczyńska M, Piasecka M, Kram A. Alteration in the mitochondria of rat spermatozoa after experimental hyperprolactinemia. Folia Histochem Cytobiol. 1999;37:87-88.

[35] Laszczyńska M, Słuczanowska-Głąbowska S, Piasecka M, Skowron J, Dębińska-Szymańska T. Germ cells with nuclear DNA fragmentation related to apoptotic cells in rat testis in experimental hyperprolactinemia induced by metoclopramide. Folia Histochem Cytobiol. 2002;40:163-164. 
[36] Laszczyńska M. Struktura i funkcja jądra i narządów dodatkowych w doświadczalnej hiperprolaktynemii wywołanej metoklopramidem. Ann Acad Med Szczecin. 1997; 36:1-84.

[37] Amiri Z, Katz Y, Weizman A, Bidder M, Snyder SH, Gavish M. Adrenal mitochondrial benzodiazepine receptors are sensitive to agents active at the dopamine receptor. Biochem Pharmacol. 1993;45:999-1002.

[38] Bjřr ro T, Johansen E, Frey HH, Turter A, Torjesen PA. Diffrent responses in little and bigbig prolactin to metoclopramide in subjects with hyperprolactinemia due to $150-170$ kD (bigbig) prolactin. Acta Endocrinol. 1993;128:308-312.

[39] Nakagawa K, Obara T, Matsubara M, Kubo M. Relationship of changes serum concentrations of prolactin and testosterone during dopaminergic modulation in males. Clin Endocrinol. 1982;17:345-352.

[40] Laszczyńska M, Różewicka L, Kuchnio M, Piasecka M, Marchlewicz M. Evaluation of spermatozoa of the rat in hyperprolactinemia induced by metoclopramide. Andrologia. 1992;24:101-108.

[41] Kinon BJ, Gilmore JA, Liu H, Halbreich UM. Prevalence of hyperprolactinamia in schizophrenic patients treated with conventional antipsychotic medications or risperidone. Psychoneuroendocrinol. 2003;28:55-68.

[42] Holland JM, Lee C. Effects of pituitary grafts on testosterone stimulated growth of the rat prostate. Biol Reprod. 1980;22: 351-335.

[43] El-Afly M, et all. Localization of type $517 \beta$-hydroxysteroid dehydrogenase, $3 \beta$-hydroxysteroid dehydrogenase, and androgen receptor in the human prostate by in situ hybridization and immunocytochemistry. Endocrinol. 1999;140:14811491.
[44] Emberton M, Mundy AR. The prostate and benign prostatic hyperplasia. In: Mundy AR, Fitzpatrick JM, Neal DE, George NJR, ed. Scientific Basic of Urology. Isis Medical Media Ltd: Oxford; 1999, pp. 13-18.

[45] Kwong J, Xuan JW, Chan PSF, Ho SM, Chan FL. A comparative study of hormonal regulation of three secretory proteins (Prostatic SecretorynProtein-PSP94, Probasin and Seminal Vesicle Secretion II) in rat lateral prostate. Endocrinol. 2000;141:4543-4551

[46] Aumuller G. Prostate gland. In: Prostate Gland and Seminal Vesicles. Aumuller G, Oksche A, Vollrath L [Eds], SpringerVerlag Berlin, Heideberg, New York; 1979, pp. 51-182.

[47] Costello LC, Liu Y, Zou J, Franklin RB. Evidence for a zinc uptake transporter in human prostate cancer cells which is regulated by prolactin and testosterone. J Biol Chem. 1999; 274:17499-17504.

[48] Wilson EM, French FS. Biochemical homology between rat dorsal prostate and coagulating gland. Purification of a major androgen-induced protein. J Biol Chem. 1980;255:1094610953.

[49] Ahonen TJ, Harkonen PL, Rui H, Nevalainen MT. PRL signal transduction in the epithelium compartment of rat prostate maintained as long-term organ cultures in vitro. Endocrinol. 2002;143:228-238.

[50] Kindblom J, Dillner K, Ling C, Tornell J, Wennbo H. Progressive prostate hyperplasia in adult prolactin transgenic mice is not dependent on elevated serum androgen levels. Prostate. 2002;53:24-33.

Submitted: 25 May, 2010 Accepted after reviews: 28 July, 2010 